\title{
Satu tahun kesintasan penderita limfoma non-hodgkin berdasarkan klasifikasi histopatologi working formulation
}

\author{
Evan Pratama Ludirdja ${ }^{1}$, Ni Made Renny A Rena ${ }^{2}$, Ketut Suega ${ }^{2}$, I Made Bakta ${ }^{2}$
}

${ }^{1}$ Program Studi Pendidikan Dokter Spesialis Penyakit Dalam Fakultas Kedokteran Universitas Udayana/RSUP Sanglah, Denpasar, Bali, Indonesia; ${ }^{2}$ Departemen/KSM Penyakit Dalam, Fakultas Kedokteran Universitas Udayana/RSUP Sanglah, Denpasar, Bali, Indonesia

Email:dokter_evan_pratama@yahoo. com

Tanggal diterima : 26 Juni 2018 Tanggal Disetujui : 18 Juli 2018 Tanggal Diterbitkan : 3 Agustus 2018
Latar belakang: Limfoma Non-Hodgkin (LNH) memiliki manifestasi dan gambaran histologi yang heterogen Berdasarkan klasifikasi Working Formulation, LNH dibagi menjadi 3, yaitu derajat keganasan rendah, menengah, dan tinggi, yang mencerminkan derajat agresifitas LNH berdasarkan gambaran histopatologiknya. Pada beberapa studi dikatakan LNH tipe indolen cenderung tumbuh lambat dan memiliki kesintasan lebih panjang dibanding tipe yang lebih agresif

Tujuan: Membandingkan median kesintasan penderita LNH dari jenis sel B berdasarkan derajat keganasannya sesuai dengan klasifikasi Working Formulation

Metode: Penelitian ini menggunakan desain kohort retrospektif, antara bulan Januari 2013 sampai Juli 2017 di RSUP Sanglah Denpasar. Analisis menggunakan Kaplan meier dan seluruh data dianalisis menggunakan SPSS.

Hasil: Dari 88 penderita LNH, diambil 38 subyek yang eligible. Dari data didapatkan sebanyak 21 penderita (55,3\%) berjenis kelamin laki-laki, dengan gambaran histopatologi terbanyak berupa Diffuse Large Cell (36,8\%). Sebanyak 3 penderita $(7,9 \%)$ termasuk dalam derajat keganasan rendah, 25 penderita $(65,8 \%)$ termasuk dalam derajat keganasan menengah, dan 10 penderita $(26,3 \%)$ dengan derajat keganasan tinggi. Median kesintasan pada LNH derajat keganasan rendah di atas 1 tahun (IK 95\%), derajat keganasan menengah 271 hari (IK 95\%), dan derajat keganasan tinggi 31 hari $(0-72,837$, IK 95\%), dengan nilai $p=0,133$, namun kelompok dengan derajat keganasan tinggi cenderung memiliki kesintasan yang lebih rendah dibanding 2 kelompok yang lain.

Simpulan: Tidak terdapat perbedaan yang signifikan kesintasan penderita LNH dengan derajat keganasan rendah, sedang, dan tinggi.

Kata Kunci: Limfoma Non-Hodgkin, working formulation

Background: Non-Hodgkin's lymphoma (NHL) often has heterogeneous histopathologic and clinical manifestations. Based on the Working Formulation classification, NHL is divided into 3 subgroup; low grade, intermediate grade, and high grade, reflecting the degree of NHL aggressiveness based on histopathologic features. In some studies said that the indolent type NHL tends to grow slowly and have longer survival than the more aggressive type.

Objective: To compare the median one year survival of B-cell type NHL patients based on degree of malignancy according to the Working Formulation classification

Methods: This study used a retrospective cohort design, data was taken from the cancer registry between January 2013 and July 2017 at Sanglah Hospital Denpasar. The analysis were using Kaplan-meier and all data were analyzed using SPSS.

Results: Of 88 people with LNH, 38 eligible subject were selected. From the data obtained as many as 21 patients (55.3\%) were male, with the most common histopathological type were Diffuse Large Cell (36.8\%). About 3 patients $(7.9 \%)$ were low grade, 25 patients (65.8\%) were intermediate grade, and 10 patients (26.3\%) were high grade. Median survival in low-grade NHL were above 1 year, intermediate grade were 271 days (IK 95\%), and high grade were 31 days $(0-72.837,95 \%$ IK), with $p$ value $=0.133$, group with high grade of malignancy tend to have lower survival than 2 other groups.

Conclusions: There were no significant differences in survival of NHL patients with low, intermediate and high grade.

Keywords: Non-Hodgkin's lymphoma, working formulation 


\section{PENDAHULUAN}

Limfoma Non-Hodgkin (LNH) adalah jenis limfoma maligna yang paling sering ditemui. Pada tahun 2012, keganasan ini termasuk dalam salah satu dari 10 keganasan dengan insiden tersering di dunia. ${ }^{1} \mathrm{Hal}$ senada juga didapatkan dari hasil RISKESDAS (Riset Kesehatan Dasar) tahun 2013 di Indonesia, insiden LNH sebesar 0,06\%, atau sekitar 14.905 orang, dan merupakan peringkat 6 keganasan tersering di Indonesia. ${ }^{2,3}$ Sedangkan di RSUP Sanglah Denpasar, insiden LNH pada tahun 2014-2015 didapatkan sebesar 24 orang, dengan dominasi tipe histopatologik DLBCL (Diffuse Large B-Cell Lymphoma) sebanyak 15 orang (60\%). ${ }^{4}$ LNH pada dasarnya merupakan kelompok keganasan limfosit yang dapat berasal dari limfosit B, limfosit T, dan kadang sel NK (Natural Killer) yang berada dalam sistem limfe, yang sangat heterogen, baik tipe histologis, gejala, perjalanan klinis, respon terhadap pengobatan, maupun prognosis. ${ }^{5}$ Dikarenakan tipe dan manifestasi yang sangat beragam itulah maka penyakit ini diklasifikasikan menjadi beberapa subkelompok.

Ada beberapa macam klasifikasi LNH yang telah dikenal baik, dimana masing-masing memiliki tujuan penggolongan, kelebihan, serta kekurangan. Dari beberapa klasifikasi yang ada, yang paling banyak diterima dan dipakai adalah berdasarkan Working Formulation (WF) yang diajukan tahun 1982, dan klasifikasi WHO/REAL (World Health Organization/ Revised European American Lymphoma) pada tahun 1997. Klasifikasi WF membagi LNH berdasarkan agresifitas tumor dengan gambaran histopatologiknya, Ada 3 kelompok LNH berdasarkan klasifikasi ini, yakni derajat keganasan rendah, meliputi; Small Lymphocytic; Follicular with predominantly Small Cleaved Cell; Follicular with Mixed Small Cleaved and Large Cell, derajat keganasan menengah, meliputi; Follicular Large Cell; Diffuse Small Cleaved Cell; Diffuse Mixed Small and Large Cell; serta Diffuse Large Cell, dan derajat keganasan tinggi, yang meliputi; Large Cell Immunoblastic; Lymphoblastic; serta Small non-Cleaved Cell Burkitt's and non-Burkitt's. ${ }^{5}$

Penderita LNH agresif memiliki karakteristik tumor dengan pertumbuhan yang cepat, besar, dan gejala yang lebih mencolok, namun memiliki sensitivitas tinggi terhadap modalitas kemoterapi. Sedangkan LNH indolen cenderung tumbuh lambat dengan manifestasi yang heterogen. Pada beberapa studi dikatakan LNH indolen memiliki kesintasan yang lebih tinggi dibanding LNH agresif. ${ }^{6}$ Namun di Indonesia belum ada studi yang melaporkan tentang kesintasan penderita LNH dengan derajat agresifitas tumor yang berbeda. Penelitian ini bertujuan untuk mengevaluasi kesintasan 1 tahun penderita LNH di RSUP Sanglah Denpasar pada tahun 2013-2017 berdasarkan klasifikasi WF.

\section{METODE}

Penelitian ini menggunakan desain kohort retrospektif, data diambil dari rekam medis semua penderita LNH dari jenis limfosit B yang datang ke RSUP Sanglah Denpasar. Kriteria inklusi adalah semua penderita LNH limfosit B datang ke RSUP Sanglah Denpasar mulai bulan Januari 2013 sampai bulan Juli 2017. Kriteria eksklusi adalah penderita dengan gambaran histologi meragukan (grey-zone lymphoma), kasus diagnosis sulit, missing data, penderita yang loss to follow up, penderita yang mengalami transformasi dari atau ke keganasan lain, serta penderita dengan penyakit komorbid berat seperti gagal jantung kronik, penyakit ginjal kronik stadium akhir, dan keganasan ganda. Sampel akan dikelompokkan menjadi 3 berdasarkan klasifikasi WF, yaitu derajat keganasan rendah (low grade), derajat keganasan menengah (intermediate grade), dan derajat keganasan tinggi (high grade). Gambaran histologi yang termasuk dalam derajat keganasan rendah yaitu; Small Lymphocytic; Follicular with predominantly Small Cleaved Cell; Follicular with Mixed Small Cleaved and Large Cell. Kelompok derajat keganasan menengah, antara lain; Follicular Large Cell; Diffuse Small Cleaved Cell; Diffuse Mixed Small and Large Cell; serta Diffuse Large Cell. Sedangkan kelompok derajat keganasan tinggi, yaitu; Large Cell Immunoblastic; Lymphoblastic; serta Small non-Cleaved Cell Burkitt's and non-Burkitt's.

Outcome yang dinilai adalah one year survival (OYS), yaitu waktu kesintasan penderita LNH sejak awal terdiagnosis sampai meninggal selama 1 tahun pengamatan karena sebab apapun. Apabila penderita masih hidup pada saat akhir studi dan penderita yang drop out sebelum akhir studi, maka akan dimasukkan dalam censored. Data deskriptif tentang karakteristik subyek disajikan dalam bentuk tabel frekuensi. Analisis kesintasan menggunakan Kaplan meier. Data kesintasan disajikan dalam bentuk tabel dan kurva kesintasan. Seluruh data dianalisis menggunakan software SPSS 22.

\section{HASIL}

Dari 88 penderita LNH, didapatkan subyek yang eligible sebanyak 38 penderita, dengan karakteristik subyek penelitian disajikan dalam Tabel 1. Dari data didapatkan sebanyak 21 penderita $(55,3 \%)$ berjenis kelamin laki-laki, dengan gambaran histologi terbanyak berupa Diffuse Large Cell (36,8\%). Berdasarkan stadiumnya, sebanyak 2 penderita $(5,3 \%)$ terdiagnosis pada stadium 1,12 penderita $(31,6 \%)$ stadium 2, 12 penderita $(31,6 \%)$ stadium 3, serta 12 penderita $(31,6 \%)$ stadium 4 . Sedangkan pengelompokan berdasarkan klasifikasi WF didapatkan 3 penderita $(7,9 \%)$ termasuk dalam derajat keganasan rendah, 25 penderita $(65,8 \%)$ termasuk dalam derajat keganasan menengah, dan 10 penderita $(26,3 \%)$ dengan derajat keganasan tinggi. Dari keseluruhan penderita, sebanyak 27 (71\%) dilakukan kemoterapi, dan 19 penderita 
(50\%) meninggal selama masa studi.

Berdasarkan analisis menggunakan Kaplan-meier (Tabel 2), didapatkan median 1 tahun kesintasan pada kelompok dengan derajat keganasan rendah sebesar lebih dari 1 tahun (IK 95\%), kelompok dengan keganasan menengah 271 hari (IK 95\%), dan kelompok derajat keganasan tinggi 31 hari (0-72,837, IK 95\%). Secara statistik tidak didapatkan perbedaan yang bermakna dari kesintasan penderita LNH berdasarkan derajat keganasannya $(\mathrm{p}=0,133)$ (tabel 3$)$, namun kelompok dengan derajat keganasan tinggi cenderung memiliki kesintasan yang lebih rendah dibanding 2 kelompok yang lain. Kurva kesintasan disajikan pada Gambar 1.

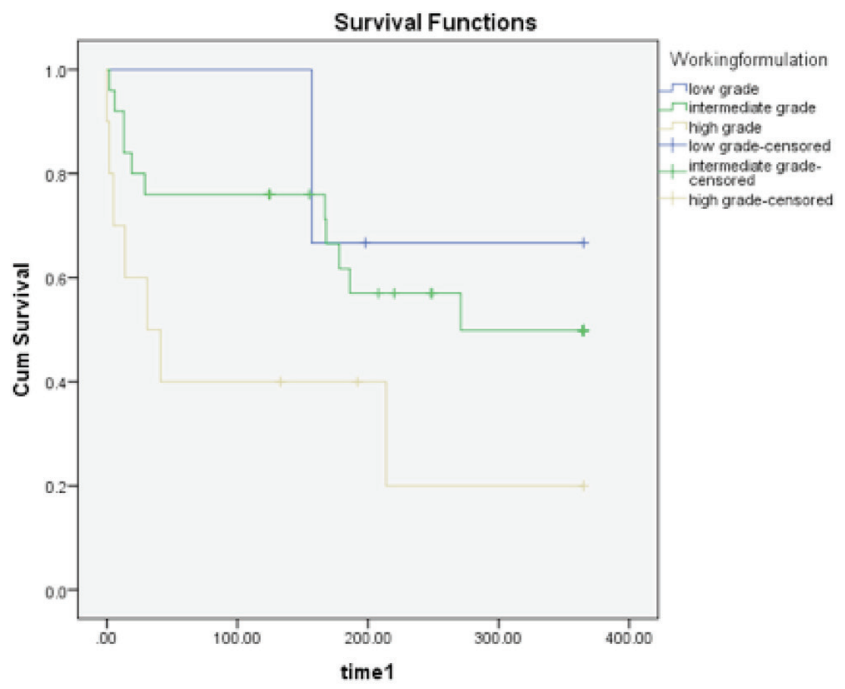

Gambar 1. Kurva kesintasan penderita LNH berdasarkan derajat keganasan (WF)
Tabel 3. Perbedaan derajat kesintasan LNH berdasarkan derajat keganasan

\begin{tabular}{llll}
\hline & Chi square & df & sig \\
\hline Log Rank & 4,037 & 2 & 0,133 \\
\hline
\end{tabular}

\section{DISKUSI}

Seperti diketahui sebelumnya, LNH dapat berasal dari limfosit B, limfosit T, maupun sel NK. Pada beberapa studi sebelumnya dilaporkan LNH dari jenis sel B memiliki insiden lebih tinggi dibanding $\mathrm{LNH}$ dari jenis sel T, dengan tipe DLBCL menempati urutan pertama insiden LNH yang tersering. ${ }^{4,6,7,8}$ Hal senada juga didapatkan pada studi ini, yakni DLBCL didapatkan sebesar 33\% dari seluruh gambaran histopatologik pada sampel. Perangai sel kanker pada LNH dapat sangat heterogen, berbeda antara tiap-tiap penderita, dapat indolen, agresif, maupun sangat agresif. DLBCL merupakan LNH dengan derajat keganasan menengah, cenderung tumbuh cepat dan dapat menjadi bulk tumor, namun memiliki respon yang baik terhadap kemoterapi CHOP sehingga apabila diagnosis dan terapi dilakukan sejak dini, tipe ini dapat memiliki kesintasan yang baik. ${ }^{9}$

Pada studi yang lain dilaporkan LNH dari jenis sel B juga memiliki kesintasan yang lebih baik secara signifikan dibanding LNH dari jenis sel $\mathrm{T}$, dan merupakan salah satu prediktor independen kesintasan penderita LNH. ${ }^{9}$ Tipe histopatologik sel B tertentu juga dilaporkan memiliki kecenderungan tumbuh lambat dan kesintasan yang lebih baik, yaitu tipe folikular limfoma, yakni kesintasan rata-rata

Tabel 1. Karakteristik subyek penelitian

\begin{tabular}{lcccc}
\hline \multicolumn{1}{c}{ Karakteristik } & Jumlah & Median & Minimum & Maksimum \\
\hline Jumlah sampel & 38 & & & \\
Umur (tahun) & & 50,5 & 14 & 77 \\
Stadium (Ann-Arbor) & 2 & rendah & Tinggi \\
Derajat keganasan (WF) & & Menengah & 0 & 365 \\
Lama pengamatan (hari) & & 173 & & \\
\hline
\end{tabular}

Tabel 2. Rerata one yearl survival (ONS) penderita LNH

\begin{tabular}{lcccc}
\hline & \multicolumn{3}{c}{ Median } \\
\cline { 2 - 5 } Derajat Keganasan (WF) & Estimasi (hari) & SE & \multicolumn{2}{c}{ Interval kepercayaan 95\% } \\
\cline { 2 - 5 } & - & - & Batas bawah & Batas atas \\
\hline Rendah & 271 & - & - & - \\
Menengah & 31 & 21,345 & 0,00 & 72,837 \\
Tinggi & 214 & 68,159 & 80,407 & 68,159 \\
Total & & & \\
\hline
\end{tabular}


1, 3, dan 5 tahun berturut-turut $87 \%$, 78,3\%, dan $60,9 \%{ }^{10,11}$. Selain itu pada studi yang sama juga dilaporkan beberapa faktor prognosis yang juga merupakan prediktor independen kesintasan penderita LNH, diantaranya skor IPI (International Prognostic Index), kadar LDH, umur, dan stadium. ${ }^{10}$ Faktor-faktor prognosis tersebut berperan penting dalam memprediksi kesintasan penderita LNH. Dengan adanya prediksi kesintasan yang akurat dapat sebagai pertimbangan dokter dalam menentukan modalitas terapi yang akan dipilih, apakah akan dilakukan terapi kuratif atau paliatif.

Pada studi ini tidak terdapat perbedaan yang bermakna kesintasan penderita LNH berdasarkan derajat keganasannya sesuai dengan klasifikasi WF. Perbedaan hasil yang didapat pada studi ini dibandingkan studi-studi terdahulu bisa dikarenakan adanya waktu pengamatan kohort yang terlalu singkat, jumlah sampel penderita LNH yang tergolong dalam derajat keganasan rendah sangat sedikit, serta terdapat 12 penderita drop out sehingga dimasukkan dalam censored. Selain itu penderita LNH yang datang ke RSUP Sanglah ini didominasi terdiagnosis pada stadium 3 atau 4 dan sekitar 29\% penderita menolak kemoterapi, sehingga turut berpengaruh pada hasil kesintasan. Beberapa hal lain yang diduga turut mempengaruhi kesintasan penderita LNH yaitu; tingkat pengetahuan penderita tentang penyakitnya, intoleransi dari efek samping dan toksisitas regimen kemoterapi, maupun masalah ekonomi dan asuransi kesehatan. Pada data median kesintasan didapatkan LNH dengan derajat keganasan tinggi memiliki kecenderungan kesintasan yang lebih rendah dibanding derajat keganasan rendah dan menengah. Hal ini senada dengan studi sebelumnya yaitu LNH dengan derajat keganasan tinggi selain tumbuh dengan cepat, juga memiliki respon yang buruk terhadap kemoterapi, sehingga memiliki prognosis yang kurang baik. ${ }^{12}$

Kelemahan studi ini adalah studi ini menggunakan desain retrospektif, yang memungkinkan adanya data yang hilang dan harus dieksklusi dari studi sehingga turut pula mempengaruhi hasil yang didapat. Selain itu perbedaan inter observer pemeriksa gambaran histopatologik memungkinkan terjadinya bias pada studi ini, dikarenakan data hasil pemeriksaan histopatologik yang ada dievaluasi oleh pemeriksa yang berbeda-beda. Lebih lanjut pada studi ini peneliti tidak melakukan wawancara langsung dan pemeriksaan kondisi aktual subyek. Studi selanjutnya disarankan menggunakan desain yang lebih baik, menggunakan waktu pengamatan kohort yang lebih lama, dan memperhatikan aspek-aspek yang dapat menimbulkan bias, serta perlu untuk dilakukan evaluasi terhadap pengaruh tiap-tiap regimen kemoterapi serta modalitas terapi yang lain terhadap kesintasan penderita LNH.

\section{SIMPULAN}

Tidak terdapat perbedaan yang signifikan kesintasan penderita LNH dengan derajat keganasan rendah, menengah, dan tinggi.

\section{DAFTAR PUSTAKA}

1. Ferlay J, Soerjomataram I, Ervik M, dkk. GLOBOCAN 2012 v1.1, Cancer Incidence and Mortality Worldwide: IARC CancerBase No.11. International Agency for Research on Cancer. 2014.

2. Pusat Data dan Informasi Kementerian Kesehatan Republik Indonesia. Data dan Kondisi Penyakit Limfoma di Indonesia. Vol. 1, Infodatin. Jakarta; 2015. 1-6 p.

3. Kementrian Kesehatan Republik Indonesia. Panduan Penatalaksanaan Limfoma Non-Hodgkin. Jakarta; 2016. 1-38 p.

4. Paramartha IKA, Rena RA. Karakteristik Pasien Limfoma Maligna di RSUP SANGLAH Tahun 2015. E-Jurnal Med. 2017;6(2):1-9.

5. Reksodiputro AH, Irawan C. Limfoma Non-Hodgkin (LNH). In: Alwi I, Salim S, Hidayat R, Kurniawan J, Tahapary DL, editors. Penatalaksanaan di Bidang Ilmu Penyakit Dalam Panduan Praktik Klinis. VI. Jakarta: Pusat Penerbitan Ilmu Penyakit Dalam; 2015. p. 2975-86.

6. Hitz F, Arndt V, Lorez M. Survival Trends for non- Hodgkin lymphoma patients in Switzerland. Natl Inst Cancer Epidemiol Regist. 2015;I(1):61-6.

7. Boffetta P. I. Epidemiology of adult non-Hodgkin lymphoma. Ann Oncol. 2011;22(Supplement 4):iv27-iv31.

8. Dwianingsih EK, Indrawati, Hardianti MS, dkk. Histopathological Features of Lymphoma in Yogyakarta, Indonesia. APJCP. 2016;17(9):4213-6.

9. Abdelhamid T, Samra M, Ramadan H. Clinical prognostic factors of diffuse large B cell non-Hodgkin lymphoma: A retrospective study. J Egypt Natl Canc Inst. 2011;23(1):17-24.

10. Jiang JN, Sun XH. The prognosis factors research on the 172 nonhodgkin lymphoma cases. Biomed Res. 2016;27(2):336-44.

11. Rimsza LM, Li H, Braziel RM, et al. Impact of histologic grading on survival in the SWOG S0016 follicular lymphoma cohort. Haematologica. 2018;1-11.

12. Jiang M, Bennani NN, Feldman AL. Lymphoma classification update: B-cell non-Hodgkin lymphomas. Expert Rev Hematol. 2017;10(5):40515.

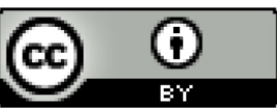

This work is licensed under a

Creative Commons Attribution 4.0

International License. 